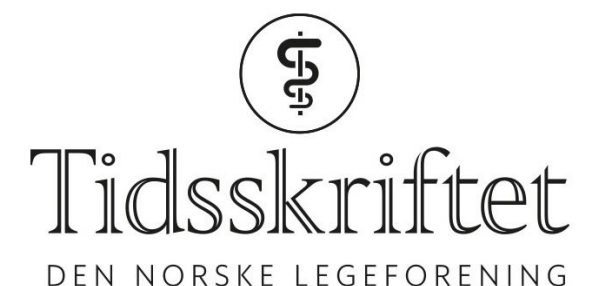

DEN NORSKE LEGEFORENING

\title{
I Herr Petters rike
}

TIDLIGERE I TIDSSKRIFTET

$\AA ̊ L A \cup G \quad F L O$

E-post: aaslaug.flo@tidsskriftet.no Tidsskriftet

Skriver man nekrologer over sykehus i våre dager? Da amtssykehuset på Alstenøya i 1926 ble flyttet fra Søvik til Sandnessjøen, kom en «forhenværende sykehuslæge ved det nu nedlagte sykehus» i Tidsskriftet nr. 23/1926 med noen velvalgte, nesten lyriske «mindeord» (Tidsskr Nor Lægeforen 1926; 46: 1120-8). Helgeland er Petter Dass' land, og sykehusbehandling kunne vel han ha trengt under sin smertefulle og langvarige nyresykdom, som til slutt tok hans liv. I sin klagesang beskriver han tilstanden slik:

En krop, opfylt med Gruus og Steen, / Har tusind Gange Breck og Meen; / Jeg troer den ey med Pen og Fier / Ud skrives kand saa som den er.

Jeg har hos mig befundet det, / Jeg er av Piine trcett og maett. / Jeg ønsker tit all Verdens Vey: / Jeg ønsker Døden, døer dog ey.

En Barnefødsel er vel strceng/ For Qvinden i sin Barselseng; / Men naar hun Fosteret har fød, / har hun forvundet all $\sin N ø d$.

Men jeg har baared hidindtil / Det Foster som mig drcebe vil, / I 6 Aar har jeg baaret det, / Ti maa jeg engang blive trett.

\section{Nordlands amtssygehus paa Helgeland.}

Av G. Winge, Sarpsborg.

(...) Stedet for Nordlands amts sykehus' virksomhet paa Helgeland, har altid været Alstenø, mest bekjendt vel ved de Syv søstre og Petter Dass. Alstenøen, som ligger ut mot leden ret ut for utløpet av Vefsenfjorden, er en i sydvest nordost retning langstrakt $\emptyset$. I samme retning løper langs størstedelen av øen en høi fjeldryg, hvis i rad liggende topper hæver sig over fjeldkammen som de Syv søstre til over 1000 meters høide. De gir hele øen dens præg og er kjendelige paa avstand: «Syv Søstre, der fletter sin’ lokker i sne, syv damer og alle saa hvide» om vinteren ja, om sommeren er de snebare. Paa indsiden mot øst styrter fjeldet brat i sjøen, og her bor ingen folk ; men paa utsiden mot vest har fjeldet et smalere eller bredere i det hele tatt flatt forland, hvor det er adskillig bebyggelse og megen dyrkbar jord. Her ligger mot nord Sandnessjøen, ved det nordlige utløp av Vefsenfjorden i leden. - 16 til $17 \mathrm{~km}$. længere syd ad landeveien kommer man til Søvik, like under den sydligste av Søstrene, Stortind (paa rektangelkartet Breitind) - og seks kilometer videre sydover ligger kirkestedet Alstahaug, hvor Petter Dass' prestegaard endnu staar, og hvor mindestøtten over ham er reist, synlig fra leden. (...) 


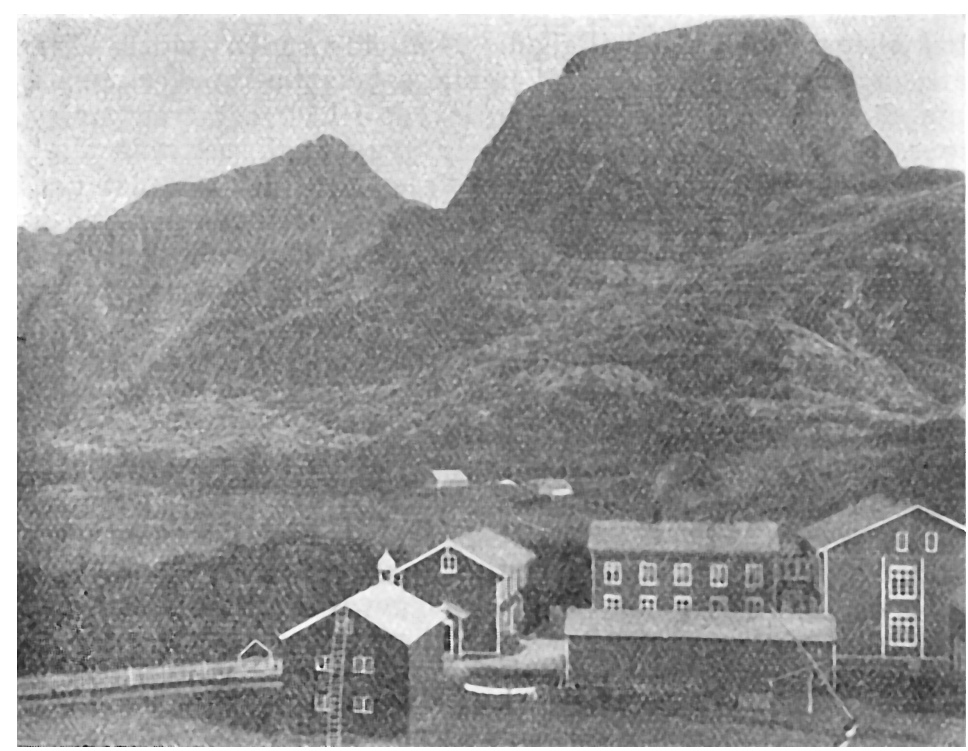

Utenfor Alsten ligger Herø sogn med en uendelighed av øer, holmer og skjær, mot nord avsluttet av den store ø Dønna - og kommer man litt op i fjeldet paa Stortind eller en av de andre Søstre, ser man utenfor Herø-komplekset Lovundens og længere nord Trænens underlige former hæve sig steilt av havet. Fra alle Søstrene har man en herlig utsigt over havet med alle de nævnte øer, helt fra Hestmanden i nord til Torghatten og Vegø i syd. I nord ser man dessuten Svartisen, og indover indlandet møt øst har man hele fjeldkomplekset i indre Ranen, Hattfjelddalen og Vefsen med Okstinderne, Brurskanken o. m. a. - en utsigt vel værd et lengere livsophold på disse kanter, som kanskje i mange andre henseeender ikke for alle vil virke indbydende og letlevelige - men hvilke morsomme og interessante vandringer og bestigninger kan man ikke ha mellem Søstrene!

Søvik sykehus ligger - eller rettere laa altsaa - omtrent under 65,55 n.br. i Alstahaug lægedistrikt, et distrikt som selv før Tjøtta og Herø i den senere tid blev fraskildt, baade var temmelig vidtstrakt, og hvor reiserne, som væsentlig var sjøturer, ofte var lange og haarde de foregik jo indtil for faa aar siden altid i aapen baat under roing ellr seil. (...)

Det var et trivelig og pent bygningskompleks som var opført paa Søvik ; røde toetages træbygninger med hvite kanter og vinduer - arrangert saa de dannet en firkantet og derved lun gaardsplass. (...)

Adkomsten til sykehuset var god, det laa centralt til, med udmerket vei baade fra nord og syd - paa Alsten - eller pr. baat eller dampskib, for hvilket der var god havn. Her var ogsaa i en lang aarække liggestedet for de lokale dampskibe, saa Søvik var det naturlige centrum og samlingssted paa øen, og sykehusets beliggenhet derved den gang selvsagt den rette. Men desværre, dette forhold blev efterhaanden forandret ve Sandnessjøens opkomst ved hurtigrutenes og de andre langfarende dampskips anløp her ; dette sted laa da ogsaa naturligere til - ved utløpet av den nordre arm av Vefsenfjorden - for lokaldampskibene som utgangs- og liggested, hvilket det ogsaa efterhaanden blev til - og hermed var igrunden Søviks skjæbne beseglet, selv om det varte mange aar inden dets endelige dom faldt ved beslutningen om bygning av det nye sykehus paa Sandnessjøen - hvortil altsaa nu isommer efter bygningens fuldførelse flytning av sykehusvirksomheten har fundet sted, og derved er Søvik traadt ut av tjeneste. Vi som har været der, vil ofte tænke tilbake paa det eiendommelige sted der i Nordlandsleden under de Syv søstre, hvor vi har tilbragt en interessant del av vort liv ; for os vil det føles underlig, at stedet ligger der øde og forlatt nu, og at den gamle tradition er brutt.

Publisert: 4. september 2017. Tidsskr Nor Legeforen. DOI: 10.4045/tidsskr.17.070o

(C) Tidsskrift for Den norske legeforening 2020. Lastet ned fra tidsskriftet.no 